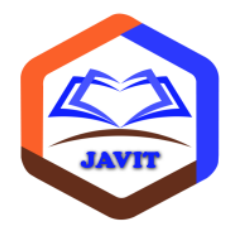

JURNAL VOKASI INFORMATIKA

(JAVIT)

Terbit online pada laman web jurnal: http://javit.ppj.unp.ac.id

DOI: https://doi.org/10.24036/javit.v2i1

ISSN: $2775-6807$

Vol. 1 No. 1 (2021) 1 - 5

\title{
Efektivitas E-Modul Berbasis Project Based Learning Selama Pembelajaran Jarak Jauh
}

\author{
1,* Indra Kurniawan Rezki, ${ }^{2}$ Joni Karnando, ${ }^{3}$ Elfi Tasrif \\ 1,2,3 Pendidikan Teknologi Kejuruan, Pasca Sarjana, Universitas Negeri Padang \\ *Coressponding author e-mail: indrakuriawanrezki@gmail.com
}

\begin{abstract}
Abstrak
Pandemic yang disebabkan oleh SARS-Cov-2 telah membuat penerapan sistem Pembelajaran Jarak Jauh (PJJ) pada dunia pendidikan. Menyikapi hal tersebut, beberapa item dalam sistem pembelajaran mesti disesuaikan dua di antaranya adalah media dan model pembelajaran. E-modul dan model pembelajaran Project Based Learning (PjBL) merupakan solusi yang tepat untuk diterapkan pada kondisi pandemic ini.Artikel ini bertujuan untuk memberikan gambaran terkait penerapan kombinasi kedua solusi tersebut terhadap mata pelajaran Simulasi Digital di SMK dengan metode literatur review. Hasil yang diperoleh yaitu penerapan e-modul yang dikombinasikan dengan model pembelajaran PjBL dinilai efektif dalam peningkatan mutu belajar pada mata pelajaran Simulasi Digital. Artikel ini diharapkan dapat menunjang pembelajaran selama sistem pembelajaran PJJ.
\end{abstract}

Kata kunci : Model Pembelajaran, Pembelajaran Jarak Jauh, E-Modul, Project Based Learning, Simulasi Digital.

(C) Lisensi: Creative Commons Attribution 4.0 International (CC BY 4.0) 


\section{Pendahuluan}

SARS-Cov-2 merupakan suatu jenis virus baru dari kelompok Coronavirus yang menyebabkan penyakit Covid-19 (Coronavirus Disease) dan telah mewabah ke sebagian besar negara di dunia sepanjang tahun 2020 termasuk Indonesia. Berbagai cara telah dilakukan untuk menghambat penyebaran virus seperti lockdown di berbagai negara. Indonesia dalam megatasi penyebaran virus ini telah mengeluarkan kebijakan Pembatasan Sosial Berskala Besar (PSBB) dan lockdown di beberapa daerah. Adapun di dalam kebijakan ini, masyarakat tidak boleh berpindah dan bepergian dari satu daerah ke darah yag lain juga adanya penerapan social distancing di antara setiap orang. Hal ini pun berdampak di berbagai aspek kehidupan, baik sosial, ekonomi, bahkan dalam pendidikan. Dalam bidang pendidikan demi mendukung kebijakan tersebut, maka diberlakukannya kebijakan belajar dari rumah atau kegiatan belajar jarak jauh baik di sekolah maupun perguruan tinggi[1].

Pembelajaran Jarak Jauh (PJJ) merupakan suatu sistem pembelajaran yang tidak berlangsung dalam satu ruangan dan tidak ada interaksi secara langsung antara guru dan siswa [2]. Penerapan PJJ di era kecanggihan teknologi dinilai sangat tepat, terutama di masa pandemi ini. Dalam mendukung penerapan PJJ, beberapa sistem pembelajaran online terkait pun dapat digunakan, seperti e-learning maupun google classroom, begitu juga platform video konferens seperti google meet dan zoom [3]. Selain adanya pendukung berupa platform yang telah tersebar merata, PJJ juga memiliki beberapa tantangan terhadap sistem pendidikan, salah satunya yaitu pada penggunaan media pembelajaran. Media pembelajaran yang biasanya berupa cetak dinilai tidak efektif digunakan dalam sistem PJJ ini. Oleh karena itu, untuk menunjang sistem pembelajaran pada saat pandemik ini diperlukan bentuk media pembelajaran yang dapat diakses oleh semua siswa dari tempat manapun. Modul elektronik (e-modul) adalah suatu modul pembelajaran dalam bentuk elektronik yang dilengkapi dengan audio, animasi, dan navigasi sehingga menjadikan pembelajaran lebih menarik [4].

Simulasi digital merupakan salah satu mata pelajaran pada K13 Sekolah Menengah Kejuruan (SMK) yang diwajibkan pada semua program keahlian kelas X. Mata pelajaran ini bertujuan agar siswa dapat menggunakan teknologi informasi dan komunikasi dengan baik[5]. Pembahasan ini bertujuan untuk memberikan evaluasi keefektifan penerapan e-modul berbasis PjBL pada mata pelajaran Simulasi Digital terutama di kondisi pandemi saat ini.

\section{Tinjauan Pustaka}

\subsection{Pembelajaran Jarak Jauh}

Pembelajaran Jarak Jauh (PJJ) merupakan sistem pembelajaran yang tidak berlangsung dalam satu tempat dan tidak terdapat interaksi langsung antara guru dengan siswa [2]. Ada beberapa kelebihan menggunakan sistem PJJ di antaranya:

1. Distribusi pendidikan dapat menjangkau ke semua tempat

2. Waktu belajar tidak terbatas

3. Siswa dapat menentukan pilihan materi sendiri

4. Materi belajar yang selalu terbarukan

5. Media maupun modul yang digunakan lebih kreatif dan komunikatif[6].

\subsection{E-Modul}

E-Modul adalah modul tanpa cetak yang didisain khusus untuk siswa belajar sendiri [5]. Ada beberapa ciri khusus suatu e-modul yaitu:

\section{Self Intruction}

Siswa mampu belajar dan memahami materi sendiri

2. Self Contained

Semua bab materi sudah terhimpun dalam satu modul.

3. Stand Alone

Satu modul tidak bergantung penggunaannya dengan modul yang lain.

4. Adaptive

Materi yang disampaikan selalu terbarukan.

5. User Friendly

Interaktif terhadap siswa.

6. Selalu tepat dalam hal redaksi dan huruf

7. Media elektronik yang digunakan beragam.

8. Terdiri dari berbagai fitur[7].

\subsection{Project Based Learning}

Project Based Learning (PjBL) merupakan model pembelajaran yang menekankan pada pembelajaran yang kompleks dimana siswa menjadi pemeran utama menggantikan guru dalam hal pemecahan masalah dan menyelesaikan proyek yang diberikan. Penggunaan model pembelajaran ini meliputi penyelesaian suatu proyek oleh siswa yang hasil akhirnya berupa suatu produk[8][9]. Adapun beberapa karakteristik PjBL yaitu: 
1. Siswa membuat kerangka kegiatan secara mandiri

2. Guru memberikan tantangan kepada siswa

3. Siswa memikirkan solusi terhadap tantangan dari guru

4. Siswa diberikan tanggung jawab secara bersama untuk menemukan solusi yang tepat

5. Selalu ada evaluasi setelah pembelajaran

6. Siswa diminta untuk melakukan evaluasi pada akhir pembelajaran

7. Solusi berupa produk dari siswa akan dilakukan evaluasi

8. Siswa dikenankan untuk berkreasi dalam solusi[10]

Dalam pelaksanaan PjBL, ada beberapa tahapan yang dibutuhkan yaitu:

1. Guru mengawali pembelajaran dengan suatu tantangan

2. Siswa membuat kerangka proyek

3. Siswa menyusun jadwal penyelesaian proyek

4. Guru mengawasi jalannya proyek

5. Guru memberikan penilaian terhadap hasil proyek siswa

6. Guru melakukan evaluasi[11]

\section{Metode Penelitian}

Metode yang_digunakan di dalam artikel review ini yaitu metode kajian pustaka berdasarkan Ramdhani_dkk [12]. Beberapa tahapan dalam metode ini yaitu memilih topik yang akan direview, mencari artikel yang berkaitan dengan topik, mengidentifikasi literatur,lalu menyusun artikel review secara sistematis. Topik yang diangkat di dalam artikel review ini adalah mengenai efektivitas pengembangan e-modul pada mata pelajaran simulasi digital yang digabungkan dengan model PjBL sebagai penunjang e-modul tersebut. Topik ini diharapkan dapat memberikan gambaran terkait pentingnya menggunakan e-modul yang dikombinasikan dengan model $\mathrm{PjBL}$ pada mata pelajaran Simulasi Digital sebagai penunjang pelaksanaan PJJ selama masa pandemik.

\section{Hasil dan Pembahasan}

\subsection{Penggunaan E-Modul Dalam Menunjang Pembelajaran di SMK}

Modul merupakan bahan ajar yang disusun sistematis berdasarkan kurikulum tertentu dan dikemas dalam bentuk satuan pembelajaran yang memungkinkan untuk dipelajari sendiri [13]. Standar efektif atau tidaknya suatu modul tergantung dapat menggantikan peran guru sebagai sumber ilmu serta bahasa yang digunakan pun dapat mudah diterima oleh siswa [14].

Seiring berkembangnya teknologi, perubahan dalam sistem pembelajaran pun terus dilakukan,salah satunya yaitu bertransformasiya modul cetak menjadi modul elektronik (e-modul). Keberadaan e-modul ini telah berhasil mendukung peran guru sebagai sumber informasi bagi siswa serta meningkatkan minat belajar siswa. Beberapa penelitian telah membuktikan tentang keefektifan emodul terhadap minat belajar siswa di antaranya yang dilakukan oleh laili 2019 dengan hasilnya terdapat peningkatan yang signifikan pada nilai tes setelah belajar dibandingkan nilai sebelum belajar [15],astalini 2019 dengan hasilnya menunjukkan nilai sangat baik pada siswa di dalam kelas percobaan maupun kelas kendali[16], pazlina 2020 dengan hasilnya menunjukkan keefektifan dalam penerapan dan nilai tes akhir pembelajaran[4], dan cahyani 2020 dengan hasilnya menunjukkan keefektifan golongan sedang [17].

\subsection{Penggunaan E-Modul Berbasis PjBL Dalam Menunjang Pembelajaran di SMK}

Pembelajaran berbasis proyek (PjBL) adalah Suatu model pembelajaran yang menekankan pada kreatifitas berfikir, pemecahan masalah, dan komunikasi [18]. PjBL yang dikombinasikan dengan e-modul dinilai akan memberikan hasil yang lebih optimal[5]. Berdasarkan perspektif ini, maka model pembelajaran jenis ini dapat menunjang PJJ saat pandemik ini. Beberapa penelitian yang telah menggunakan e-modul berbasis PjBL dalam sistem pembelajaran di SMK di antaranya laili 2019 dengan hasilnya terdapat peningkatan yang signifikan pada nilai tes setelah belajar dibandingkan nilai sebelum belajar [15], winaya (2016), priatna (2017), simarmata (2017), dan suantara (2019) umumnya memperoleh respon yang baik dari siswa dan sangat baik dari guru untuk penerapan PjBL[19][20][21], dan [22].

\subsection{Pengembangan Kombinasi E-Modul Dengan Model PjBL Pada Simulasi Digital}

Simulasi digital merupakan salah satu mata pelajaran dasar program keahlian K13 untuk kelas X Sekolah Menengah Kejuruan (SMK). Mata pelajaran ini lebih memberikan siswa kesempatan dalam menyampaikan ide yang ditemukannya sendiri maupun memodifikasi ide yang sudah ada.[5] dan [23] telah menguji e-modul berbasis 
PjBL dengan kesimpulan terbukti berhasil dalam meningkatkan minat belajar siswa.

\section{Kesimpulan}

Berdasarkan hasil review yang diperoleh, dapat disimpulkan bahwa penerapan e-modul dengan kombinasi BjPL dinilai efektif jika diterapkan pada mata pelajaran Simulasi Digital di SMK terutama selama pandemic seperti yang terjadi saat ini.

\section{Daftar Rujukan}

[1] N. K. S. Astini, "Pemanfaatan teknologi informasi dalam pembelajaran tingkat sekolah dasar pada masa pandemi covid-19," Lampuhyang, vol. 11, no. 2, pp. 13-25, 2020.

[2] D. Munir and M. IT, "Pembelajaran jarak jauh berbasis teknologi informasi dan komunikasi," Bandung Alf., 2009.

[3] A. Latip, "Peran literasi teknologi informasi dan komunikasi pada pembelajaran jarak jauh di masa pandemi Covid-19," EduTeach J. Edukasi dan Teknol. Pembelajaran, vol. 1, no. 2, pp. 108-116, 2020.

[4] N. Pazlina and U. Usmeldi, "Pengembangan EModul Dasar-dasar Listrik dan Elektronika Berbasis Problem-Based Learning," J. Pendidik. Tek. Elektro, vol. 1, no. 1, pp. 71-74, 2020.

[5] N. P. A. Wijayanti, L. P. E. Damayanthi, I. M. G. Sunarya, and I. M. Putrama, "Pengembangan E-Modul Berbasis Project Based Learning pada Mata Pelajaran Simulasi Digital untuk Siswa Kelas X Studi Kasus di SMK Negeri 2 Singaraja," J. Pendidik. Teknol. dan Kejuru., vol. 13, no. 2, pp. 184-197, 2016.

[6] A. G. Prawiyogi, A. Purwanugraha, G. Fakhry, and M. Firmansyah, "Efektifitas Pembelajaran Jarak Jauh Terhadap Pembelajaran Siswa di SDIT Cendekia Purwakarta," J. Pendidik. Dasar, vol. 11, no. 01, pp. 94-101, 2020.

[7] I Lestari, Pengembangan bahan Ajar Berbasis Kompetensi: Sesuai dengan Kurikulum Tingkat satuan Pendidikan. Padang: Akademia Permata, 2013.

[8] Trianto, Model Pembelajaran Terpadu: Konsep, Strategi, dan Implementasinya dalam Kurikulum Tingkat Satuan Pendidikan (KTSP). Jakarta: Bumi Aksara, 2014.

[9] M. Wena, Strategi Pembelajaran Inovatif Kontemporer: Suatu Tinjauan Konseptual Operasional. Jakarta: Bumi Aksara, 2014.

[10] Kemdikbud, Materi Pelatihan Guru Implementasi Kurikulum 2013 Tahun Ajaran
2014/2015: Mata Pelajaran IPA SMP/Mts. Jakarta: Kementerian Pendidikan dan Kebudayaan, 2014.

[11] Rais, "PROJECT-BASED LEARNING: Inovasi Pembelajaran yang Berorientasi Soft skills.," digilib.unm.ac.id, 2010.

[12] A. Ramdhani, M. A. Ramdhani, and A. S. Amin, "Writing a Literature Review Research Paper: A step-by-step approach," Int. J. Basic Appl. Sci., vol. 3, no. 1, pp. 47-56, 2014.

[13] A. R. Purwanto and S. Lasmono, Pengembangan Modul. 2007

[14] E. Ronaldo and A. Aslimeri, "Pengembangan Modul Pembelajaran Dasar Listrik dan Elektronika Berbasis Course Review Horay," J. Pendidik. Tek. Elektro, vol. 1, no. 1, pp. 156-159, 2020.

[15] I. Laili, "Efektivitas Pengembangan E-Modul Project Based Learning pada Mata Pelajaran Instalasi Motor Listrik," J. Imiah Pendidik. Dan Pembelajaran, vol. 3, no. 3, pp. 306-315, 2019.

[16] A. Astalini, D. Darmaji, W. Kurniawan, K. Anwar, and D. Kurniawan, "Effectivenes of Using E-Module and E-Assessment," 2019.

[17] A. E. M. Cahyani, T. Mayasari, and M. Sasono, "Efektivitas E-Modul Project Based Learning Berintegrasi STEM Terhadap Kreativitas Siswa SMK," J. Ilm. Pendidik. Fis., vol. 4, no. 1, pp. 15-22, 2020.

[18] T. Laviatan, "Innovative Teaching and assessment Method: QBI and project based learning," Math. Educ. Res. J., vol. 10, no. 2, pp. 105-116, 2008.

[19] I. K. A. Winaya, I. G. M. Darmawiguna, and I. G. P. Sindu, "Pengembangan E-Modul Berbasis Project Based Learning pada Mata Pelajaran Pemrograman Web Kelas X di SMK Negeri 3 Singaraja," J. Pendidik. Teknol. dan Kejuru., vol. 13, no. 2, pp. 198-211, 2016.

[20] I. K. Priatna, I. M. Putrama, and D. G. H. Divayana, "Pengembangan e-modul berbasis model pembelajaran project based learning pada mata pelajaran videografi untuk siswa kelas X Desain Komunikasi Visual di SMK Negeri 1 Sukasada," J. Nas. Pendidik. Tek. Inform. JANAPATI, vol. 6, no. 1, pp. 70-78, 2017.

[21] E. A. Simarmata, G. S. Santyadiputra, M. C. ST, and D. G. H. Divayana, "Pengembangan E-Modul berbasis model pembelajaran Project 
Based Learning pada mata pelajaran pemrograman desktop kelas XI rekayasa perangkat lunak di SMK Negeri 2 Tabanan," KARMAPATI (Kumpulan Artik. Mhs. Pendidik. Tek. Inform., vol. 6, no. 1, pp. 93-102, 2017.

[22] K. D. Suantara, I. G. M. Darmawiguna, and N. Sugihartini, "Pengembangan E-Modul Berbasis Model Pembelajaran Project Based Learning Pada Mata Pelajaran Pemrograman Grafik Kelas Xii Rekayasa Perangkat Lunak Di Smk Negeri 2 Tabanan," KARMAPATI (Kumpulan Artik. Mhs. Pendidik. Tek. Inform., vol. 8, no. 2, pp. 404-414, 2019.

[23] K. R. Winatha, D. R. N. Suharsono, and K. Agustini, "Pengembangan E-modul Interaktif Berbasis Proyek Pada Mata Pelajaran Simulasi Digital Kelas X di SMK TI Bali Global Singaraja," J. Teknol. Pembelajaran Indones., vol. 8, no. 1, 2018. 